\title{
The Learning Effectiveness of Application of Computer Assisted Instruction to C-Level Technical Test of Computer Software for Special Educational Students
}

\author{
Wan-Ju Chen and Hong-Min Lin
}

\begin{abstract}
Whether Special educational students in a vocational school can work and integrate into this competitive society in the future, surely vocational skills teaching of vocational education is one of the elements of success. From the educational perspective, technical vocational education is through the implementation of skills test; for students' perspective, there must be taken in account their interest in learning and employment needs. For Special educational students in a vocational school, if they can obtain C-level technical certificate, it will be a sure way to increase their self-confidence. After graduation, that can also increase student employment opportunities, and improve the success rate of employment. In the modern teaching environment, how to use information technology and how to appropriate all kinds of teaching technology or media into curriculum design and teaching methods --these have become a challenge for teachers. The purpose of this paper is to explore the effectiveness of Computer Assisted Instruction (CAI) in the application of $\mathrm{C}$ -level Technical Learning of Computer software applications for special educational students in a vocational school. The A-B-A-B reversion design of single tester was used in the study, while the independent variable is computer-aided instruction teaching and dependent variable as learning effectiveness of the tester. In this study, after four weeks of experiments, we found that the application of computer-aided instruction to train Special educational students in the computer software C-level technical learning, can improve student learning effectiveness.
\end{abstract}

Index Terms-Special educational student, computer-assisted instruction, technical certificate.

\section{INTRODUCTION}

In the educational environment, with the educational ideals of teaching and learning, those who are physically and mentally handicapped can enter the general high school for 12-year compulsory education. The students with mild mental retardation also have the opportunity to enter higher vocational education. This educational measure will allow physically and mentally handicapped students more time for career and independent living preparation as they transition from school to real life situation.

In accordance with the provisions of the Vocational School Law, the Special Education Law and its Enforcement Rules, The purpose of vocational special educational course

Manuscript received January 18, 2017; revised April 13, 2017.

Wan-Ju Chen is with the Department of Business Administration, Taiwan Shoufu University. No.168, Nanshih Li, Madou district, Tainan City 72153, Taiwan (e-mail: post123465@gmail.com).

Hong-Min Lin is with the Department of Counselling, National Taichung Industrial High School. No.191, Gaogong Rd, South District, Taichung City, 40241, Taiwan (e-mail: tcivs2266@yahoo.com.tw). is to provide opportunities for people with mild mental retardation to attend the vocational program in order to cultivate the capacity of individuals, societies and professional adaptations to become an independent person [1].

Many studies have demonstrated and confirmed the working potential of persons with intellectual disabilities. With appropriate vocational education and training, they will be able to move into the job market, contribute to society and find self-confidence. In this competitive environment, where "the fittest is out of the way," the mentally handicapped need to meet the job requirements in addition to the basic competencies required for their job [2]. The teaching programs and training in schools and vocational training institutions will enable disabled persons to acquire relevant vocational skills before employment. During the teaching period with physically and mentally handicapped students, researchers were deeply impressed by how successful these students have been in teaching and training for 12 years to be able to work smoothly in a competitive job market.

Skills certification system is used to evaluate the vocational education and training performance way, but also to ensure that the national labour standards approach [3]. The main purpose of the certification system is to measure the effectiveness of national vocational and technical education and vocational training, to improve the quality of the ability to work, to enhance and protect personal work opportunities and rights, and to meliorate the social status of individuals [4].

From a practical perspective, the implementation of the certification will provide the employees with a certain standard of technical capacity, and to ensure product quality, as well as to protect public health and reduce the occurrence of occupational disasters [5]. From an educational perspective, technical vocational education through the implementation of skills test, it will accommodate students' interest in learning and employment needs [6].

Therefore, for special educational students in a vocational school, if they can obtain a C-level technical certificate, it will be sure to increase their self-confidence. After graduation, it can also increase student employment opportunities, and improve the success rate of employment. However, from the practical working experience view of a researcher, with special educational students in a vocational school participating in a $\mathrm{C}$-level technical test certificate, half of these students have a problem in the technical operation course. So these students in the technical operation course need some special learning strategies to help them pass the technical examination. For example, Repeating exercises in 
the course of technical operational learning activities. Also teachers must use a number of strategies to show these techniques to facilitate technical operational learning.

Reference [7] pointed out that the future development trend of special education is necessarily needed in computer science and technology. Reference [8] believed that the computer science and technology is essential for special education, especially so in computer-assisted teaching software and equipment development and application. The use of computers to assist students in learning has become a new teaching trend. Computers can provide multiple sensory stimuli, which can attract students' attention, enhance learning motivation and improve their learning through vivid pictures, text symbols and sounds [9]-[11].

For students with mental retardation, stored information in a short period of time is rather limited and often forgotten are the skills just learned. Special assistance and teaching is required for development of individual differently in physically and mentally handicapped students. Adopting multimedia content instruction can be repeated and fully enacted to enhance students' memory of learning content, and adopting computer-assisted instruction can control their own learning progress according to their learning level and speed.

In short, computer-assisted instruction can respond to many needs and objectives, and reinforce students' learning. The use of multimedia content to assist teaching enhances teaching effectiveness and through the use of computers improves the quality of learning. Based on the above, in order to explore whether this computer-assisted instruction can enhance students' learning outcomes, the researchers intend to use computer-assisted instruction in the C-level training course of the Higher Vocational Education Special Class.

\section{ThE PURPose OF THE STUdY}

Based on the above research motivation, the purpose of the study was described below:

- To discuss the effect of Computer Assisted Instruction (CAI) on the application of C-level technique in the training of computer software for students in special education classes.

- To explore the views of computer assisted instruction (CAI) in students of special education classes.

\section{The ResEARCH MethodS}

The experimental design was by A-B-A-B reversion experiment of Single Subject Research Design. The following was a description of the structure of the study, the research object, the research tools, the experimental design and the data analysis.

\section{A. Independent Variable}

The independent variable of this study was "Computer Assisted Instruction"(CAI). The researchers provide computer software applications C-level multi-media teaching materials, and teach the subject how to use multimedia materials.

\section{B. Dependent Variable}

The dependent variable of this study was the results of the C-level technical learning in the computer software application, while the score of the skill test was used to calculate the scores of the subjects.

\section{Study Subjects}

From the special education classes of a certain senior vocational high school a willing student was selected, as a computer-assisted teaching experimenter. The basic information of the subjects is shown in Table I as below:

TABLE I: THE SUBJECT’S BASIC ABILITY INFORMATION OF EXPERIMENTAL

\begin{tabular}{|c|c|c|c|c|}
\hline Subjects & Gender & Intelligence & $\begin{array}{l}\text { C - level } \\
\text { written } \\
\text { test } \\
\text { results }\end{array}$ & Advantage \\
\hline $\begin{array}{l}\text { The } \\
\text { experimenter }\end{array}$ & Male & 75 & 70 & $\begin{array}{l}\text { Interested in } \\
\text { the } \\
\text { computer; } \\
\text { the computer } \\
\text { has the basic } \\
\text { ability to } \\
\text { operate; } \\
\text { hoping to } \\
\text { obtain } \\
\text { C-level } \\
\text { certificate of } \\
\text { computer } \\
\text { software } \\
\text { application }\end{array}$ \\
\hline
\end{tabular}

\section{Research Tool}

Computer Assisted Multimedia: A multimedia CD was provided to the subject by the researcher and instructs the subject how to use the multimedia.

Learning Performance Test: The experimenter was scored using the technical Scoreboard to calculate.

Computer-Assisted Instruction Interview: In order to understand the experimenter 's perception and understanding of "computer-assisted instruction", participants were interviewed.

Experimental design:

- Baseline period (A1): This stage did not implement the intervention strategy, only the implementation of the baseline phase of the test. This study was designed with a single subject, so a minimum of three trials were performed during the baseline phase prior to strategy intervention. The primary purpose was to assess the performance of the subject's original learning outcome in order to obtain stable baseline data. When the baseline data of the subject was stabilized, then he was involved in the computer-assisted instruction process. There was a test-question group for each test time, three times during a total test.

- Experimental treatment period (B1): In this study, the computer-assisted multi-media teaching experiment was a computer-assisted multimedia teaching to the subject, and instructed the subject how to use the system. Individual observation and study were conducted to explore the effect of computer-assisted instruction on the learning outcomes of participants. There was a test-question group for each test time, six times during a total test. 
- Baseline period (A2): This stage did not implement the intervention strategy, only the implementation of the baseline phase of the test. This study was designed with a single subject, so a minimum of three trials were performed during the baseline phase prior to strategy intervention. The primary purpose was to assess the performance of the subject's learning outcome in order to obtain stable baseline data. When the baseline data of the subject was stabilized, then he was involved in the computer-assisted instruction process. There was a test-question group for each test time, at least three times during a total test.

- Experimental treatment period (B2): In this study, the computer-assisted multi-media teaching experiment was a computer-assisted multimedia teaching session with the subject, and instructed the subject how to use the system. Individual observation and study were conducted to explore the effect of computer-assisted instruction on the learning outcomes of participants. There was a test-question group for each test time, six times during a total test.

Data analysis:

Data from this study was analyzed using the "visual analysis" and "C statistics" of a single experimental design to understand the changes in subjects who did not receive computer-assisted instruction and those who did receive computer-assisted instruction to analyze the effects of the experiment. After the end of the experimental study, the experimenter was interviewed to understand the feelings and views of the students after receiving computer-assisted whole process of learning.

\section{RESUlTS AND DisCUSSION}

\section{A. Fractional Graph Analysis of C-Level Technical Test in the Baseline and Treatment Period}

The subject participating in this experiment, the test scores at the baseline period $\mathrm{A} 1$, the treatment period $\mathrm{B} 1$, the baseline period A2, and the treatment period B2, as shown in Fig. 1

At baseline A1, experimenter scored 49,53,51 points in $\mathrm{C}$ -level technical test. In the treatment period B1, the C-level technical test results appear to increase the situation, to the ninth evaluation, which reached 74 points. When entering the baseline period A2, the score dropped to 52 points. However after entering the treatment period B2, the C-level technical test score increased to 78 points. This indicated that the increase in the score of C-level technical test of the experimenter was due to the treatment of computer-assisted multimedia application. In short, the study found that the computer-assisted multimedia application presented the effectiveness of the experimenter. The experimenter in the baseline period $\mathrm{C}$-level technical test scores remained a stable performance, significantly increased the score of the treatment period, showing Computer-assisted instruction had a good effect on the experimenter's C-level technical test.

\section{B. The Visual Analysis Results of Baseline and Treatment} Periods

\section{1) Visual analysis of the subject during each phase of the experiment}

Table II was a summary of the results of the visual analysis of the subject at each stage of the experiment. The experimenter in the baseline A1 had a first score of 49 and a final score of 51 , the level change was +2 . This showed that the experimenter in the baseline A1 had a stable trend, range of 53 to 49 points and the performance level was also very stable.

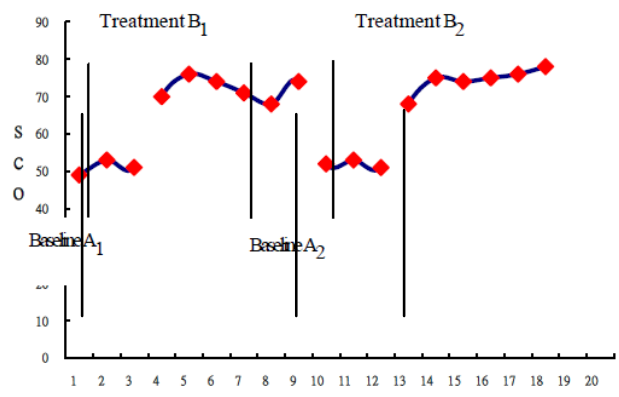

Fig. 1. The score of C-level technical test of the subject in the different period A1, B1, A2, B2.

After entering the treatment period B1, the performance of the trend was stable, showing that the score in the C-level technical test was stability. The high score of 76 points, the lowest score of 68 points, the standard range was from 76 to 68 points. In the treatment period B1, the score of the first evaluation was 70, and the score of the last evaluation was 74 , so that the level change was +4 . The mean level of performance B1 in the treatment period was 72 points higher than the average score 51 in the baseline period A1.

TABLE II: SUMMARY OF RESULTS OF THE VISUAL ANALYSIS OF THE SUBJECT DURING THE VARIOUS STAGES OF THE EXPERIMENT

\begin{tabular}{|c|c|c|c|c|}
\hline \multirow[b]{2}{*}{ Stage order } & \multicolumn{4}{|c|}{ The experimenter } \\
\hline & $\begin{array}{l}\text { Baseline } \\
\text { Period A1 }\end{array}$ & $\begin{array}{c}\text { Treatment } \\
\text { Period } \\
\text { B1 } \\
\end{array}$ & $\begin{array}{l}\text { Baseline } \\
\text { Period A2 }\end{array}$ & $\begin{array}{c}\text { Treatment } \\
\text { Period } \\
\text { B2 } \\
\end{array}$ \\
\hline Stage length & 3 & 6 & 3 & 6 \\
\hline $\begin{array}{c}\text { Trend } \\
\text { Forecast }\end{array}$ & $\longrightarrow$ & - & - & - \\
\hline $\begin{array}{c}\text { Trend } \\
\text { Stability }\end{array}$ & $\begin{array}{c}\text { Stability } \\
100 \%\end{array}$ & $\begin{array}{c}\text { Stability } \\
100 \%\end{array}$ & $\begin{array}{c}\text { Stability } \\
100 \%\end{array}$ & $\begin{array}{c}\text { Stability } \\
100 \%\end{array}$ \\
\hline $\begin{array}{c}\text { Performance } \\
\text { level }\end{array}$ & 51 & 72 & 52 & 74 \\
\hline $\begin{array}{c}\text { Level } \\
\text { Stability }\end{array}$ & $\begin{array}{c}\text { Stability } \\
100 \%\end{array}$ & $\begin{array}{c}\text { Stability } \\
100 \%\end{array}$ & $\begin{array}{c}\text { Stability } \\
100 \%\end{array}$ & $\begin{array}{c}\text { Stability } \\
100 \%\end{array}$ \\
\hline $\begin{array}{l}\text { Standard } \\
\text { Range }\end{array}$ & $51-49$ & $76-68$ & $53-51$ & $76-68$ \\
\hline Level change & $\begin{array}{c}51-49 \\
+2 \\
\end{array}$ & $\begin{array}{c}70-74 \\
+4 \\
\end{array}$ & $\begin{array}{c}52-51 \\
-1 \\
\end{array}$ & $\begin{array}{c}78-68 \\
+10 \\
\end{array}$ \\
\hline $\begin{array}{l}\text { Note: } \\
\text { 1. "Stage Leng } \\
\text { 2. "Performan } \\
\text { increases. } \\
\text { 3. "Performan } \\
\text { 4. "Trend Stab } \\
\text { more than } 85 \% \\
\text { 5. "Level Ran } \\
\text { 6. "Level chan } \\
\text { last day of the }\end{array}$ & $\begin{array}{l}\text { " means the } \\
\text { Trends" " } \\
\text { Level" repr } \\
\text { ty" and "Stal } \\
\text { for the stabil } \\
\text { " is the lowe } \\
\text { " means the } \\
\text { eriod. }\end{array}$ & $\begin{array}{l}\text { mber of time } \\
\text { indicates ste } \\
\text { ts the avera } \\
\text { Stability" Re } \\
\text { less than } 85 \\
\text { oint and the } \\
\text { rformance g. }\end{array}$ & $\begin{array}{l}\text { evaluation. } \\
\text { trend; "/" } \\
\text { orrect rate f } \\
\text { to [12], } 85 \% \\
\text { or the chang } \\
\text { hest point in } \\
\text { etween the }\end{array}$ & $\begin{array}{l}\text { licates trend } \\
\text { ach stage. } \\
\text { a benchmark, } \\
\text { s stage. } \\
\text { day and the }\end{array}$ \\
\hline
\end{tabular}

The experimenter had a range of 53 to 51 points at baselineA2, showing a stable trend and stable performance; the baseline score of A2 was 52 for the first time and the final score of 51 for the baseline period, the level change was -1 
points.

After entering the treatment period B2, the performance of the trend was stable, showing its smooth grade in the C-level technical test. The average performance score of the treatment period $\mathrm{B} 2$ was 74 points higher than the average score, 52, points of the baseline period A2. The highest score of 78 points, the lowest score of 68 points in the treatment period $\mathrm{B} 2$, so the standard range from 78 to 68 points. In the treatment period $\mathrm{B} 2$, the score of the first evaluation is 68 points, and the score of the last evaluation is 78 points, so the level change was +10 .

\section{2) The results of the visual analysis of changes in the} experimenter between adjacent stages

Table 3 was a summary of the results of the visual analysis of changes in the experimenter between adjacent stages. The data of table 3 showed that the trend of the baseline period A 1 to the treatment period B1 was stable. The subject had a change of +19 between the stages in which the baseline period A1 entered the treatment period B1.The difference between the score of the last evaluation in the baseline period A1 of 51 and the score of the first evaluation of the treatment B1 of 70 was +19 . Performance level of overlap of $0 \%$, showing that the improvement of $\mathrm{C}$-level technical test results of the experimental treatment was very effective.

It was also known that the trend of the baseline period A2 to the treatment period B2 was smooth. The subject's score varied by +17 between the baseline period $A 2$ entered into the treatment period $\mathrm{B} 2$.That is, the score of the last evaluation of the baseline period A2 was 51 points and the first assessment score of the treatment period B2 was 68 points. The overlap of the performance levels was $0 \%$, indicating that the experimental treatment was very effective in improving the $\mathrm{C}$-level technical test.

TABLE III: SUMMARY TABLE OF VISUAL ANALYSIS RESULTS OF CHANGES IN THE EXPERIMENTER BETWEEN ADJACENT STAGES

\begin{tabular}{|c|c|c|c|c|c|c|}
\hline & \multicolumn{6}{|c|}{ The experimenter } \\
\hline $\begin{array}{l}\text { adjacent } \\
\text { stages }\end{array}$ & \multicolumn{2}{|c|}{$\begin{array}{c}\text { Baseline Period } \\
\text { A1/Treatment } \\
\text { Period B1 }\end{array}$} & \multicolumn{2}{|c|}{$\begin{array}{c}\text { Treatment } \\
\text { Period B1/ } \\
\text { Baseline Period } \\
\text { A2 }\end{array}$} & \multicolumn{2}{|c|}{$\begin{array}{c}\text { Baseline Period } \\
\text { A2/ Treatment } \\
\text { Period B2 }\end{array}$} \\
\hline Trends in & - & - & - & - & - & - \\
\hline $\begin{array}{c}\text { changes } \\
\text { and effects }\end{array}$ & \multicolumn{2}{|c|}{ No change } & \multicolumn{2}{|c|}{ No change } & \multicolumn{2}{|c|}{ No change } \\
\hline $\begin{array}{c}\text { Trend } \\
\text { stability } \\
\text { changes }\end{array}$ & $\begin{array}{l}\text { Stable } \\
\text { to } \\
\text { stable }\end{array}$ & $\begin{array}{l}\text { Stable } \\
\text { to } \\
\text { stable }\end{array}$ & $\begin{array}{l}\text { Stable } \\
\text { to } \\
\text { stable }\end{array}$ & $\begin{array}{l}\text { Stable } \\
\text { to } \\
\text { stable } \\
\end{array}$ & $\begin{array}{l}\text { Stable } \\
\text { to } \\
\text { stable }\end{array}$ & $\begin{array}{l}\text { Stable } \\
\text { to } \\
\text { stable }\end{array}$ \\
\hline $\begin{array}{l}\text { Level of } \\
\text { change }\end{array}$ & \multicolumn{2}{|c|}{$\begin{array}{c}51-70 \\
+19\end{array}$} & \multicolumn{2}{|c|}{$\begin{array}{c}74-52 \\
-22\end{array}$} & \multicolumn{2}{|c|}{$\begin{array}{c}51-68 \\
+17\end{array}$} \\
\hline $\begin{array}{l}\text { Percentage } \\
\text { of overlap }\end{array}$ & \multicolumn{2}{|c|}{$0 \%$} & \multicolumn{2}{|c|}{$0 \%$} & \multicolumn{2}{|c|}{$0 \%$} \\
\hline
\end{tabular}

Note:

1. "Adjacent stages" represents the comparison between two adjacent stages. 2. "Level change" refers to the difference between the last data point in the previous stage and the first data point in the latter stage.

3. " Percentage of overlap " refers to the ratio of the number of data points falling within the data point range of the previous period in the data points of the later stage.

Based on the results of visual analysis, at the baseline period, the experimenter's scores were maintained at a steady state, into the treatment period, in the C-level technical test grade increased significantly. Therefore, its effectiveness to computer-assisted application teaching strategy on improving the C-level technical test scores.

\section{3) The results of simplified time series analysis}

In this study, simplified time-series analysis [13] was applied. That is, $\mathrm{C}$ statistics to assist visual analysis and $\mathrm{Z}$ scores to show the test results. The $\mathrm{C}$ statistic was intended to test the significance of trend changes in time series data, when the $\mathrm{Z}$ score was not significant, it indicated that the data point was stable. If the $\mathrm{Z}$ score was significant, it indicated that the data point had obvious trend. C Statistics was not only testing the data points of each stage but also testing the combining two stages whether stable or not. When the baseline and treatment periods were combined, the data were tested to be significant, indicating a significant trend in experimental processing.

The results of the simplified time series analysis of the experimenter within and between the stages were shown in Table 4, Summary Table of the Simplified Time Series of the Subject. The performance analysis of the experimenter during the baseline period $\mathrm{A} 1$ and the treatment period $\mathrm{B} 1$, the statistical analysis results of the $\mathrm{Z}$ value was2.53, up to .01 statistical level. And the performance analysis between the baseline period A2 and the treatment period B2, the statistical analysis results of the $\mathrm{Z}$ value was 2.82 , up to .01 statistical level. These mean that the experimenter in the baseline period and treatment period for the C-level technical test score was presented on the continuous progress. That is, the experimental of computer-assisted instruction had a significant effect. The results of this study are consistent with [9] and [11].

Based on a result of the simplified time series analysis of the performance analysis of the two stages of the baseline period and the treatment period, after the intervention of computer-assisted instruction, the experimenter showed a significant upward trend and a positive treatment effect on the performance of the C-level technical test. Furthermore, the experimenter's performance at the baseline and treatment periods was stable. Therefore, the results of the simplified time series analysis were consistent with the results of the visual analysis.

TABLE IV: THE SUMMARY TABLE OF THE SIMPLIFIED TIME SERIES OF THE SUBJECT

\begin{tabular}{|c|c|c|c|c|c|}
\hline \multicolumn{6}{|c|}{ SUBJECT } \\
\hline & ect & Stage & $\mathbf{C}$ & Sc & $\mathbf{Z}$ \\
\hline \multirow{13}{*}{ Subject } & \multirow{6}{*}{$\begin{array}{l}\text { Baseline } \\
\text { Period } \\
\text { A1/Treat } \\
\text { ment } \\
\text { Period } \\
\text { B1 }\end{array}$} & Baseline & & & \\
\hline & & Period & & & \\
\hline & & A1+Treatm & .74 & .29 & $2.53 * *$ \\
\hline & & $\begin{array}{l}\text { ent Period } \\
\text { B1 }\end{array}$ & & & \\
\hline & & Baseline & -.25 & .35 & -.71 \\
\hline & & $\begin{array}{l}\text { Treatment } \\
\text { Period B1 }\end{array}$ & -.05 & .34 & -.14 \\
\hline & \multirow{7}{*}{$\begin{array}{l}\text { Baseline } \\
\text { Period } \\
\text { A2/Treat } \\
\text { ment } \\
\text { Period } \\
\text { B2 }\end{array}$} & Baseline & & & \\
\hline & & Period A2+ & .83 & .30 & $2.82 * *$ \\
\hline & & Treatment & .05 & .50 & 2.02 \\
\hline & & Period B2 & & & \\
\hline & & Baseline & -25 & 35 & -71 \\
\hline & & Period A2 & -.25 & .35 &.$- / 1$ \\
\hline & & $\begin{array}{l}\text { Treatment } \\
\text { Period B2 }\end{array}$ & .51 & .34 & 1.51 \\
\hline
\end{tabular}

4) Subject's view of computer-assisted instruction 


\section{experiment}

The C-level Technical test of Computer Software Application had 15 question-groups, and each question-group had three parts. When the teacher instructed steps of C-level technical test every time, the experimenter needed to remember all steps. Unfortunately, the experimenter always forgot the process steps or did not know how to remember them. On the other hand, Multimedia teaching materials was divided into three parts of each question-group, the experimenter could pause multimedia learning at any time, special when the experimenter did not understand the steps, he could repeat to see again. And a step-by-step exercise, it was easy to remember the steps of each question- group. The teacher gave multimedia materials, the preparing $\mathrm{C}$-level technical test became a lot easier, and the results were better.

In the process, the researcher observed that students showed a strong sense of participation in computer-assisted instruction. The result of [14] study indicated that computer-assisted instruction (CAI) was more effective than traditional teaching in that it can arouse students' interest in learning, less learning frustration and improve learning attitude. This study also found the same as The result of [14] study.

\section{CONCLUSION AND SugGeStion}

\section{A. Conclusion}

The subject receiving computer-assisted multimedia teaching was able to maintain a steady range of performance at baseline period. Into the treatment period, the grade of the $\mathrm{C}$-level technical test has increased significantly. That is, in the treatment period, C-level technical test scores of the subject increased.

Therefore, this study showed that the computer-assisted multimedia teaching had improved the results of treatment score, such computer-assisted teaching can enhance the effectiveness of C-level technical test of the degree of mild mental retardation students.

\section{B. Suggestion}

\section{1) On teaching aspect}

This study found that mild mental retardation students in the process of receiving computer-assisted teaching, the Clevel technical test scores had been significantly improved. As long as these kinds of students were familiar with the use of computer-assisted teaching, they could also get the C-level technical certificate as other normal students. Therefore, the C-level technical training of the mild mental disable students should be integrated into the computer-assisted multimedia teaching strategies.

\section{2) Suggestions for future research}

In this study, computer-assisted instruction (CAI) was implemented using a single subject approach, and in the future, experimental teaching methods can be used to gain a better understanding of the effects of computer-assisted learning.

This study was based on the computer software C-level technical training as the research area. Further study can be used in other C-level technical training as the study target to understand whether computer-assisted teaching is useful for other subjects of learning.

The subject of this study was a student with mild mental disablement. In the future, Study may be tried to see if computer-assisted multimedia teaching is appropriate for students with other types of obstructions.

\section{REFERENCES}

[1] Ministry of Education, "The Vocational courses Outline of Special education classes of senior secondary school, Taipei: Ministry of Education, 2000

[2] D.E. Brolin, "Vocational preparation of person with handicapped children and youth," Columbus, OH: Charles E. Merrill, 1982.

[3] Council of Labour Affairs, "Compilation of relevant laws and regulations about technician skill verification," Taipei: Vocational Training Council, Ministry of Labour of the Executive Yuan, 2000.

[4] Z. L. Kang, "Strengthen the skills test to Improve industrial technology and service quality," Employment and Training, vol. 15, no. 4, pp. 3-5, 1997.

[5] S. Chen, "The study of Improve the implementation of student skills test for vocational schools," Taipei: Department of Technological and Vocational Education of Ministry of Education, pp. 19-20, 1996.

[6] X. Q. Xiao, "The evaluation of commissioned skill verification," Employment and Training, vol.18, no.4, pp. 5-7, 2000.

[7] W. F. Guo, "Special children 's psychology and education," Taipei: Wen Jing, 2002.

[8] R. B. Lewis, "Special education technology," California: Brooks/Cole, 1993.

[9] R. H. Huang, "The function and standard of digital Learning Management System," Information and Education, vol. 89, pp. 21-22, 2002.

[10] C. Y. Chin, "The influential factors in the e-learning of junior high school students," National Kaohsiung Normal University, 2005.

[11] S. Russ, "10 reasons e-learning is a successful training tool," Multi-Housing News, vol. 138, no. 24, 2003.

[12] J. Tawney and D. L. Gast, "Single subject research in special education," Columbus, OH: Charles E. Merrill, 1984.

[13] W. W. Tryon, "A simplified time-series analysis for evaluating treatment interventions," Journal of Applied Behaviour Analysis, vol. 15, no. 3, pp. 423-429, 1982.

[14] M. C. Chen, "Opportunities, challenges and responses of students with mental and physical disabilities in digital learning environment," Special Education Textbooks and Teaching, pp. 129-151, 2003.

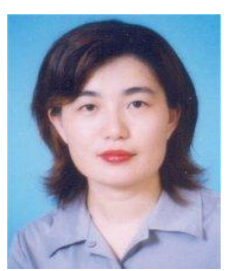

Wan-Ju Chen was born on April 5, 1967. She is the Ph.D of the Department of Industrial Education and Technology at National Changhua University of Education in Changhua city, Taiwan, R.O.C. She is an assistant professor in Business Administration Department at Taiwan Shoufu University, Taiwan. She has published in ICIC express letters, an International Journal of Research and Surveys, and IJIET, International Journal of Information and Education Technology. Her research interests include intellectual capital, knowledge management, human research management, e-learning and education.

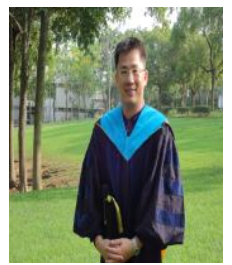

Hong-Min Lin was born on May 8, 1973. He is the $\mathrm{Ph} . \mathrm{D}$ of the Department of Industrial Education and Technology at National Changhua University of Education in Changhua city, Taiwan, R.O.C. He is a teacher at Taichung Industrial Vocation School and part-time associate professor in the Department of Special Education at National Taichung University of Education, Taiwan. He has published in ICIC express letters, an International Journal of Research and Surveys, and IJIET, International Journal of Information and Education Technology. His research interests include instruction of special education, e-learning and career education. 